\title{
Kantian Forgiveness: Fallibility, Guilt and the Need to become a Better Person. Reply to Blöser
}

\author{
Dr Paula Satne (University of Wolverhampton)
}

This is a post-peer-review, pre-copyedit version of the article published in Philosophia. The final authenticated version is available online at:

https://link.springer.com/article/10.1007/s11406-020-00188-4

\begin{abstract}
In 'Human Fallibility and the Need for Forgiveness', Claudia Blöser (2019) has proposed a Kantian account of our reasons to forgive that situates our moral fallibility as their ultimate ground. Blöser argues that Kant's duty to be forgiving is grounded on the need to be relieved from the burden of our moral failure (guilt), a need that we all have in virtue of our moral fallible nature, regardless of whether or not we have repented. Blöser claims that Kant's proposal yields a plausible account of the normative status of forgiveness. Kant classifies the duty to be forgiving as a wide (imperfect) duty of virtue, and according to Blöser, this means that Kantian forgiveness is elective in the sense that forgiveness is good in general (i.e. an attitude that we have moral reason to adopt) but without being obligatory in each particular case. In the course of presenting her own reconstruction of Kant's account, Blöser also objects to some aspects of an interpretation of Kant's theory of forgiveness which I had previously defended in my paper 'Forgiveness and Moral Development' (2016). Although there are a lot of points of agreement between our interpretations, the aim of this article is to highlight four key points of disagreement. These issues are worth discussing because they have implications not only for a plausible interpretation of a recognisable Kantian account of forgiveness but also for wider debates in the contemporary literature on forgiveness. First, I show that Kant is not committed to a form of weak situationism as suggested by Blöser and that Kant's grounding of the duty to be forgiving does not appeal to moral luck. Second, I argue that although Kant's duty to be forgiving is elective in one sense of the term, it is not elective in another important sense of the term, and that it is in fact better not to interpret Kantian imperfect duties as being elective. Third, I show that awareness of moral fallibility per se does not provide a morally appropriate ground for forgiveness and offer an alternative reconstruction of Kant's account- in which fallibility plays a role, but it is not the main reason to forgive. Finally, I argue that Blöser's account of the need to be forgiven is not recognisable Kantian because, from a Kantian perspective, repentance is a necessary condition for the desirability and, in fact, the very possibility of ameliorating our own guilt.
\end{abstract}

\section{Introduction}

In a paper recently published in this journal, 'Human Fallibility and the Need for Forgiveness', Claudia Blöser (2019) has proposed a Kantian account of our reasons to forgive that situates our moral fallibility as their ultimate ground. Blöser argues that Kant's duty to be forgiving is grounded on the need to be relieved from the burden of our moral guilt, a need that we all have in virtue of our moral fallible nature, regardless of whether or not we have repented. In the course of presenting her own 
reconstruction of Kant's account, Blöser also objects to some aspects of an interpretation of Kant's theory of forgiveness which I had previously defended in my paper 'Forgiveness and Moral Development' published in this journal in 2016. Blöser's analysis is very illuminating and it has helped me to better understand some aspects of Kant's position. Moreover, it might seem that an advantage of Blöser's interpretation is that it takes seriously an assertion that Kant makes in the very same passage in which he establishes a duty to be forgiving. Kant writes "[the] human being has enough guilt of his own to be greatly in need of [forgiveness]" (1797/1991, MS 6:460). ${ }^{1}$ In this paper I do not aim to reply to all the points made by Blöser which either implicitly or explicitly challenge my interpretation. In some cases, I do not have anything to say, and, in other cases, I accept her points as valid. Instead, I will focus only on four key points of disagreement between our readings which I think are worth discussing because they have implications not only for a plausible interpretation of a recognisable Kantian account of forgiveness but also for wider debates in the contemporary literature on forgiveness.

Blöser's proposal is an attempt to present an interpretation of Kant that is also acceptable on systematic grounds. I will argue that some aspects of her proposal are not plausible interpretations of a recognisable Kantian theory of forgiveness, while other aspects of her argument are not convincing on systematic grounds. In section 2, I start by providing a brief account of Kant's definition of forgiveness. In section 3, I show that Kant is not committed to a form of weak situationism as suggested by Blöser and that Kant's grounding of the duty to be forgiving does not appeal to moral luck. In section 4, I argue that although Kant's duty to be forgiving is elective in one sense of the term, it is not elective in another important sense of the term. In fact, Kant does not even use the term 'elective.' In Kant's terminology the duty to be forgiving is an imperfect duty of virtue, and as such, it commands the cultivation of a forgiving character through the adoption of a forgiving maxim. I will argue that it is better not to read imperfect duties as being supererogatory and thus they should not be taken to be elective in Blöser's sense. In section 5, I argue that awareness of moral fallibility per se does not provide a morally appropriate ground for forgiveness. Hence, there are good reasons to reject this view on systematic grounds. Fortunately, there is space for an alternative reading of the Kantian argument in support of the duty to forgive, one that takes into account various important aspects of Kant's practical philosophy. In my reconstruction of Kant's account, fallibility plays a role but it is not the main reason to forgive. Finally, in section 6, I discuss Blöser's account of the Kantian need for forgiveness. Blöser aims to provide an account of the need which is not restricted to repentant wrongdoers. She argues that we have a need to be relieved of the burden of our moral failure (guilt) and that other's forgiveness plays a role in providing such relief. I argue that this account of moral guilt is not recognisably Kantian because, from a Kantian perspective, repentance is a necessary condition for the desirability and, in fact, the very possibility of ameliorating our own guilt.

\section{Kant's characterisation of forgiveness}

Kant's characterisation of forgiveness is open to different interpretations. In the Lectures on Ethics (Vigilantius), Kant claims that "forgiveness is the remission of compensation or payment" (1793/ 1997 LE 27: 689). Kate Moran (2013) has drawn on this passage in order to argue that Kant views forgiveness

\footnotetext{
${ }^{1}$ Citations to Kant's work will reference the page number of the Akademie edition and also provide the year of original publication as well as the year of publication in translation. I also provide abbreviations of Kant's works for easy reading. Translations and abbreviations used are indicated in the bibliography.
} 
as requiring a change of action. Moran argues that the compensation or payment in question is to be understood broadly to comprise "the actions that we undertake in order to be either materially restored, or to have our rights restored (or, presumably, both)" (2013, p. 423). However, the key passages in the Metaphysics of Morals and other passages in the Lecture on Ethics ${ }^{2}$ suggest an emotion based account. Kant describes forgiveness as "refrain[ing] from repaying another's enmity with hatred out of mere revenge" (1797/1991, MS 6:461). Here, forgiveness is seen as an individual's personal and private response to wrongdoing, which involves overcoming the hateful desire for excessive revenge. Ernesto Garcia (2011) has argued that Bishop Butler's account of forgiveness involves overcoming excessive resentment (i.e. hateful vengeance). ${ }^{3}$ Indeed, in this passage, Kant comes close to endorsing a Butlerian account of forgiveness. However, taken at face value, this definition is problematic. Kant believes that hate and excessive vindictiveness are impermissible attitudes. If forgiveness is defined in this way, then we would be under an obligation to forgive in all situations, thus making forgiveness a perfect, not an imperfect, duty. ${ }^{4}$ However, Kant does not advocate forgiving in all cases ${ }^{5}$, so it is difficult, in this case, to see how Kant could be recommending that sometimes the right thing to do is to "hate another out of mere revenge." Thus, both Blöser and I opt to interpret Kant as maintaining that forgiveness is a wide duty that involves overcoming appropriate resentment understood broadly to include various negative emotions ${ }^{6}$ that are appropriate responses to responsible wrongdoing. ${ }^{7} \mathrm{My}$ interpretation also emphasises that the duty to be forgiving is an imperfect duty, and as such, it commands the adoption of a forgiving maxim. To adopt a forgiving maxim, in my view, is to cultivate a forgiving character, that is, a willingness to forgive wrongdoers under circumstances that are deemed appropriate. The maxim of forgiveness involves cultivating forgiving attitudes by critically evaluating certain negative emotions that are typically felt towards wrongdoers and refusing to endorse those that, on reflection, we deem morally inappropriate. It involves also embarking on some forgiveness practices (i.e. actions) which are deemed appropriate in light of the circumstances. ${ }^{8}$ Because of this, I interpret Kant as offering a flexible and pluralistic account of forgiveness which involves both a change of emotions and/or a change of actions depending on the circumstances. This interpretation allows us to combine the different passages in both the Metaphysics of Morals and Lectures on Ethics. Moreover, the pluralistic model is convincing on systematic grounds. ${ }^{9}$ Therefore, we can say that on the issue of the definition, Bloser's and my interpretation are broadly in agreement. In the following sections, I discuss four points of disagreement between our interpretations.

\section{Kant and situationism}

\footnotetext{
${ }^{2}$ See e.g. 1784-5/1997 LE 27: 435 and 1793/ 1997 LE 688-9.

${ }^{3}$ See also Blöser, 2019, p. 13.

${ }^{4}$ Moran, 2013, p. 421; Blöser, 2019, p. 13.

5 1797/1991, MS 6:461. See Satne, 2016, section VI.

${ }^{6}$ We both provide explanations of how Kant can account for the idea that emotional responses can either be controlled or, at least, shaped by the agent. See Blöser, 2019, pp. 12-13 and Satne, 2016, pp. 1033-35.

7 See Blöser, 2019, p. 14; Satne, 2016, p. 1032.

${ }^{8}$ Satne, 2016, p. 1034.

${ }^{9}$ I am convinced by Geoffrey Scarre's argument that we cannot give a strict definition of forgiveness because overcoming the negative emotions commonly associated with wrongdoing might be neither necessary nor sufficient for forgiveness (See Scarre, 2004, pp. 25-31). Kant's account is well suited to accommodate a flexible and pluralistic model because Kantian imperfect duties of sympathy involve the adoption of maxims which can be understood as principles of cultivating one's character through a variety of practices including the cultivation of some emotional responses (See Satne, 2016, esp. p. 1034).
} 
In a footnote to their paper 'In defense of Unconditional Forgiveness,' Garrard and McNaughton claim that their account has some similarities to Kant's account of forgiveness (2003, p.55, fn. 19). One of my aims in 'Forgiveness and Moral Development' was to show that such affinity was unlikely given that Kant does not maintain as strong a form of situationism as the one endorsed by Garrard and McNaughton. Blöser's aim, by contrast, is to emphasise the similarities between Kant's and Garrard and McNaughton's positions (2019, p.1). Like them, Blöser wants to allow for the possibility of unconditional forgiveness (p. 16)- while I argued that the Kantian duty to forgive is conditional on repentance. According to Garrard and McNaughton, moral fallibility provides a reason to forgive because it grounds solidarity with the wrongdoer. They claim that awareness of one's moral fallibility is intimately connected to the claim that whether or not we do wrong is, at least partly, a matter of moral luck. It is our shared humanity with the offender, which has at its core "common moral frailty", that provides a reason to forgive unconditionally (2003, pp. 54, 57). Similarly, Blöser proposes to interpret Kant's claim that we have a duty to forgive "because [the] human being has enough guilt of his own to be greatly in need of [forgiveness]" (1797/1991, MS 460) as meaning that we are all in need of forgiveness due to our moral fallible nature. According to Blöser, this claim grounds Kant's derivation of a wide duty to be forgive $(2019$, p. 2). For Blöser, "moral fallibility and awareness of moral luck are not per se reasons to forgive. Rather they lead to our having concern for the wrongdoer, which is then a reason to forgive" (2019, fn. 22). She adds, "moral fallibility plays a role in our duty to forgive because it grounds our need for forgiveness" (p. 6). In section 6, I discuss Blöser's claim that forgiveness answers to our need to be relieved from the burden of our moral guilt. Here I discuss Blöser's interpretation of Kant as committed to a form of weak situationism which entails that our moral fallibility stems from a weak form of moral luck.

Garrard and McNaughton connect the idea of moral fallibility to the question of moral luck. Firstly, they endorse a form of circumstantial luck by claiming that: (1) it is likely "that there are circumstances in which we too would have done, if not what the wrongdoer did, some similarly awful deed" (p. 55). Secondly, they endorse a form of constitutive luck when they claim that: (2) "even if I could not, as I now am, do what the offender did, nonetheless had my early (and ongoing) circumstances been less favourable, I might have become the kind of person who could act in this way" (p. 54). In "Forgiveness and Moral development', I worried that claims (1) and (2) amounted to an endorsement of a form of situationism and claimed that such a strong form of situationism is incompatible with responsibility, and in particular, with a Kantian theory of responsibility: "[t]he claim that what we do is ultimately determined by our circumstances is a form of situationism, which is clearly alien to Kant. Whatever the merits of Garrard and McNaughton's approach, we can safely conclude that it is not the one advocated by Kant" $(2016$, p. 1036). This strong form of situationism is incompatible with Kant's theory of rational agency, which I read as entailing that we are morally responsible for our actions insofar as they flow from freely adopted maxims and ultimately from our most fundamental moral disposition. Now, Blöser also rejects claims 1 and 2. Thus, on the issue of situationism our disagreement does not prima facie seem deep. It is clear that Kant would reject these claims too. In fact, Blöser rejects claim 1 for reasons similar to mine: it rests on an implausible assumption that we cannot distinguish more virtuous persons from less virtuous persons. ${ }^{10}$ Moreover, Blöser also rejects claim 2: "It remains unclear...the sense in which "I" could have been another person -one similar to the wrongdoer. If I really had developed into a vastly different person (in morally relevant respects),

${ }^{10}$ Blöser, 2019, p. 3 and Satne, 2016, p. 1036. 
in what sense would the resulting person still be "me" as I stand here now, the victim of a wrong? The reference of the " $I$ " in the thought "I could be similar to the wrongdoer" is altogether unclear, and a thought that is so difficult (and perhaps impossible) to make sense of should not be essential to our understanding of forgiveness" (p. 4). Here Blöser's point is both convincing and illuminating and in fact provides further support for my original point: Kant should not be seen as endorsing a strong form of situationism as the one endorsed by Garrard and McNaughton.

Yet, Blöser's aim is to argue that awareness of moral fallibility provides "an ultimate ground of our reasons to forgive" (p. 1). So, her strategy is to show that there is a more general thesis concerning circumstantial luck, which is the common core of both Kant's and Garrard and McNaughton's positions and which is relevant for forgiveness:

$\left(1^{*}\right)$ There are likely to be circumstances in which we too would fail morally.

Now it is true that $\left(1^{*}\right)$ might be implied by (1) but my original objection was directed to Garrard and McNaughton's endorsement of (1). Blöser says that "Garrard and McNaughton are not committed to the thesis that we are fully determined by our circumstances" (p. 7). It is not clear or obvious that this is the case as they explicitly defend (1), not merely $\left(1^{*}\right)$. So, Blöser and I can agree that (1) should be rejected within the framework of Kant's practical philosophy. In fact, as I will explain in what follows, I also think that Kant is committed to $\left(1^{*}\right)$. However, we still disagree because Blöser sees $\left(1^{*}\right)$ as providing support for a form of weak situationism whereas I will deny this in what follows.

Blöser links $\left(1^{*}\right)$ to moral luck: we are all morally fallible because either we have already committed a wrong in the past, or if we haven't, it could be just a matter of luck that our evil disposition has not yet been manifested. I also think that Kant is committed to $\left(1^{*}\right)$ but for a different reason. I will argue that Kant is not committed to a form of weak situationism, and although I read Kant as allowing for one form of moral luck, I do not think that Kant's commitment to $\left(1^{*}\right)$ follows from his commitment to this form of moral luck. Instead, it follows directly from his theory of radical evil (1793/1998, RGV 6:32) - that is, the view that our original disposition involves a tendency to prioritise the demands of self-love over moral demands -and his theory of moral development. Kant thinks that moral development requires a revolution of the heart which involves a firm resolution to make the moral law the supreme principle of all acts. ${ }^{11}$ But even after-or during ${ }^{12-}$ the revolution, moral progress always represents a struggle for us (1797/1991, MS 6:409). This means that even after the revolution we might still find it difficult to comply with some moral demands. ${ }^{13}$ Here I do not have space to address the issue of moral luck in all its complexity but on the reading that I favour, Kant can only allow for one form of moral luck: "luck with respect to whether or not the fundamentally evil disposition is ever

\footnotetext{
${ }^{11}$ For an explanation and defense of this claim see Satne, 2016, section IV, esp. pp. 1042-3. .

12 Kant says that the choice of evil Gesinnung (i.e. the fundamental disposition) is an 'intelligible deed' that does not occur in time (1793/1998, RGV 31) which is sometimes taken to imply that the choice of a good Gesinnung is equally timeless. The challenge is then to explain the relation between the timeless revolution and the gradual process of moral self-improvement involved in a project of moral self-transformation. Some authors solve the problem by arguing that the process of overcoming radical evil occurs simultaneously with the process of improving the morality of one's maxims, a process that takes place over the course of a person's life (Sussman 2005b p. 173; Korsgaard 1996, p. 181) while others are willing to allow that there is a sense in which we can say that the revolution can be placed at a moment of a person's life (Drogalis, 2013, p. 166). The point I am making here about moral progress and the ongoing struggle to achieve moral perfection is supposed to be compatible with both readings (see Satne, 2016, p. 1043).

${ }^{13}$ For a more detailed examination of this point, see Satne, 2016, p. 1044.
} 
externally manifested" (Satne, p. 1037). ${ }^{14}$ Thus, I can agree with Blöser's claim that "any finite sequence of good conduct does not exclude the possibility that a person has a morally bad disposition. This is a possibility that holds for everybody, since on Kant's view nobody can be sure about their fundamental maxim" (p. 5). However, although I agree with this claim, in what follows I am going to argue that Kant's endorsement of $\left(1^{*}\right)$ does not imply an endorsement of situationism, not even a weak one.

Blöser defines strong situationism as the view that "situational factors are more important than facts about character in explaining the behaviour of the agent" (p. 6, fn 18). As we saw, strong situationism is clearly incompatible with Kant's views on moral responsibility and Kant's theory of rational agency. Kant believes that our actions stem from freely adopted maxims, not that they are determined by situational factors. ${ }^{15}$ According to Blöser, $\left(1^{*}\right)$ implies a weak form of situationism because it implies that "what we do, and hence our moral record, is in some way a function of the circumstances" (p. 6, fn 18). However, Blöser points out that $\left(1^{*}\right)$ is not incompatible with moral responsibility in Kant's sense because it does not imply that what we do is determined by our circumstances, that is, $\left(1^{*}\right)$ does not necessarily imply full determinism. Instead, it only commits Kant to the view that what we do "is influenced by our circumstances" although these influences "[do] not undermine our capacity to act morally (and thus our moral responsibility)" (p. 7). In short, Kant's alleged weak situationism amounts to the following claim: (i) our behaviour is influenced by the circumstances.

Now I think that (i) is a bit cryptic. Moreover, Blöser does not fully explain or develop the sense in which it can be said that circumstances 'influence' behaviour. She only says that "circumstances may influence us, for example, by presenting obstacles for morally good behaviour" (p. 7). However, I think that (i) is also open to two readings: a trivial reading and a substantive reading. The substantive reading implies a form of weak situationism but I will argue that Kant is only committed to the trivial reading. The reason is that although it is true that circumstances often present us with obstacles, ultimately, for Kant, what we do is always a function of our character (understood in Kantian terms as the maxims that we endorse). I interpret Kant's ethics as an ethics of character, not circumstances. On the first reading, the claim is a trivial one: what we do is in some sense influenced by the circumstances. Even if we assume that a revolution of the heart has taken - or is taking- place, perfect virtue is beyond our reach and moral progress always represents a struggle for us. Therefore, it is still likely that there will be circumstances in which we might be tempted to act immorally. This is not because circumstances directly influence what we end up doing (which would be a more substantive claim), but because in certain circumstances the inclinations that tempt us to act immorally -which are likely to be different for each person because inclinations are shaped by our faculties of desire and our personal histories- will either become available or stronger. To give a simple example from prudential reasoning: I might not eat cake if there is no cake in the house. But if I break my diet and eat the cake that it is available in the house the reason is not because the availability of cake influences in any significant way what I end up doing. It is my decision to endorse my desire for cake that is my downfall. However, the desire comes about or becomes stronger when there is cake in the house. So the circumstances (cake in the house) influence what I do (eat the cake despite the fact that I am on a diet) because I decide to endorse my desire for cake. The action is still free as it stems from a maxim

\footnotetext{
${ }^{14}$ See also Blöser, 2019, fn. 22. For a defense of this reading of Kant, see Satne (2013).

${ }^{15}$ I argued for this interpretation of Kant's theory of rational agency in 2016, esp. section IV. Blöser also interprets Kant as excluding a form of strong situationism which involves determinism (2019, p. 7).
} 
that I freely adopt. I have a weak character, at least when it comes down to cake. But what I do is an expression of my character, my maxim, and thus my responsibility. Circumstances here influence what I do in a trivial sense: had I not had cake in the house I would not have eaten it, but what I end up doing is an expression of my choices, my maxims, and ultimately my character. A more disciplined person might not have been tempted by their desire for cake even in the presence of cake. ${ }^{16}$

In the case of temptations to act immorally, the fact that there are likely to be circumstances in which I too would fail morally does not show that what I do is 'influenced by the circumstances' in any substantive sense. If I end up acting immorally, what that shows is that I have perhaps been unlucky in actually encountering the circumstances in which my evil fundamental maxim is finally externally manifested. I read Kant's theory of virtue as supporting a somehow paradoxical conclusion: we are still responsible for our evil disposition even when we have managed to live our entire life (as a matter of luck) without having to face the circumstances that would make this disposition manifest. ${ }^{17}$ Moreover, for Kant, even a virtuous agent, who by hypothesis has affected a revolution of the heart and possess a good disposition, is not completely beyond temptation to act immorally on occasion (Kant, 1793/1998, Rel 47-8). ${ }^{18}$ For Kant, we all have our own particular temptations because our inclinations depend on our faculties of desire which are shaped by our personal histories. Succumbing to a temptation to act immorally would either be evidence of an evil disposition or, at the very least, proof that we are still struggling to improve morally, that is, that there are circumstances in which our inclinations become difficult to resist or overcome. These considerations show that Kant is only committed to a trivial reading of (i). But the trivial reading of (i) does not endorse situationism, not even of the weak form, because it does not commit Kant to the view that "what we do, and hence our moral record, is in some way a function of the circumstances" (Blöser, 2019, p. 6). Instead, what we do is a function of our character, the maxims that we adopt, and the desires that we endorse. However, we are imperfect beings who struggle to develop perfect characters, so for all of us, there are likely to be circumstances in which we too would fail morally. ${ }^{19}$

\footnotetext{
${ }^{16}$ Thank you to an anonymous referee for Philosophia for presenting me with the following objection. My example fails because in the example, the action is both a function of the circumstances (had I not had cake in the house I would not have eaten it) and of character (I have the desire for cake, and I decide to endorse it). I do not deny that there is a sense in which the circumstances influence my action (had I not had cake in the house I would not have eaten it). However, my point is that this sense is a trivial one (e.g. if it is not a sunny day, I cannot sunbathe), that is, in order for me to be able to do certain things some other things have to be the case (or be available). It seems to me that Blöser's weak situationism requires a substantive reading of (i), that is, that circumstances themselves are direct influences in what I end up doing. However, this does not seem to sit well with Kant's theory of action. To see this, I introduce a slight modification of the example. If I dislike cake (perhaps I had a bad indigestion as a child), then I will not eat it even though it is available. The circumstances themselves are not direct influences on action but sometimes allow inclinations to become stronger or available. For Kant, I maintain, is the inclinations that influence my action, i.e. when I decide to endorse them.

${ }^{17}$ I argue for this interpretation of Kant's theory of virtue in Satne (2013).

${ }^{18}$ See Satne, 2016, p. 1044.

${ }^{19} \mathrm{~A}$ perhaps more interesting kind of cases, in which it might seem that what we do is more deeply influenced by our circumstances, are cases in which we have no way to act rightly because we live in a structurally unjust society such that, despite our best efforts, we cannot but be implicated in wrongdoing. In her article, Blöser does not discuss this type of case. However, Allais (2015) and Williams (2018) have recently discussed them. Allais discusses the moral dilemma of whether or not to give money to a beggar while Williams discusses our complicity with climate change. Here I do not have space to consider these cases, but I simply note that although these cases might initially look like good examples of cases in which what we do is deeply influenced, or even
} 
4. Forgiveness is not elective, but an imperfect duty of virtue

Blöser grounds the duty to be forgiving on the fact that we all have a need to be forgiven and a wish for this need to be fulfilled. Since we have this wish and this need we cannot coherently adopt a maxim of refusing to forgive in principle, that is, we cannot adopt a maxim of unforgiveness. However, as the duty is imperfect or wide ${ }^{20}$ we are not under an obligation to forgive all the time or as much as we can. Blöser and I agree that the duty to be forgiven is wide or imperfect but we disagree to the extent that Blöser maintains, and I deny, that Kantian forgiveness is 'elective.' Kant clearly classifies the duty to be forgiving as one of the duties of sympathy, which, together with the duties of gratitude and beneficence, constitute the duties of love to other men. These duties are wide or imperfect so the question then becomes whether wide duties can be understood as elective. The first thing to note is that the term 'elective' is not a term used by Kant. The notion of elective forgiveness is widely discussed in the contemporary literature on forgiveness. However, 'electiveness' is a slippery notion that is not always clearly and consistently defined in the literature. Blöser starts by noting that to conceptualise forgiveness as a wide duty involves presenting it as "something that is good in general, i.e. an attitude that we have moral reason to adopt, without making forgiveness obligatory in each particular case" $(2019$, p. 8). I find the claim a bit mysterious as we are not told what it means to 'adopt an attitude of forgiveness in general' which nevertheless does not translate into a duty to forgive in particular cases. Blöser goes on to develop the point that, for Kant, forgiving is elective by drawing on Lucy Allais's characterisation of the notion of electiveness (Allais, 2013). According to Allais, to claim that forgiveness is elective is not incompatible with saying that there are moral reasons to forgive. Blöser takes up two central implications of the claim that forgiveness is elective: (1) forgiveness cannot be legitimately demanded, hence the wrongdoer cannot have a right to be forgiven and (2) forgiveness is like a 'gift' from the victim that she may give or withhold without being deemed irrational. ${ }^{21}$

Blöser maintains that understanding forgiveness as a wide duty allows us to preserve "these two aspects of electiveness, while adding the idea that we have a moral reason to be forgiving in general" (p. 9). I believe that Kant's notion of imperfect duty can lend support to (1), however, I do not think that a Kantian account can also endorse (2). That is, I agree that, for Kant, forgiveness is elective but only in the sense that it does not correspond to a right of the wrongdoer to be forgiven. This follows directly from the fact that the duty to be forgiving is not perfect, an aspect of Kant's position that I have also previously emphasised. ${ }^{22}$ Yet, at the same time, Kant claims that there is a duty to be forgiving (1797/1991, MS 6:460-1). Owing to this, from a Kantian perspective, it does not seem right to say that forgiveness is merely elective, completely optional, an issue of mere inclination, or a gratuitous gift, which is entirely at the victim's discretion. Indeed, the notion of an elective duty sounds to me somewhat like an oxymoron. There is a tension between, on the one hand, claiming that there

determined, by our circumstances, from a Kantian perspective, it turns out that these circumstances are the expressions of our collective agency in which we are ultimately complicit and, for which, we bear responsibility.

${ }^{20}$ As Blöser, I follow the standard interpretation that sees the pair wide/narrow and imperfect/perfect as making the same distinction (e.g., Blöser 2019 and Timmermann, 2005).

${ }^{21}$ See Blöser, 2019, p. 8; Allais, 2013, esp. p. 642, and Hallich, 2016, p. 1009.

${ }^{22}$ See Satne, 2016, p. 1051. 
are moral reasons to forgive, while on the other hand maintaining that these moral reasons are somehow rationally optional or not binding. ${ }^{23}$ I will return to this point shortly.

In order to create space for the notion of elective forgiveness within the Kantian framework, Blöser sides with Hill's interpretation (1992) which takes some imperfect duties to be supererogatory (2019, n. 27). Moreover, Blöser also endorses a relaxed interpretation of the latitude of imperfect duties citing Hill: "[w]e ought to act on the duty 'sometimes' and, 'accordingly, one may avoid doing so at any time (though not at all times) that one feels inclined' (Hill, 1992, p. 159)." ${ }^{24}$ This interpretation of Kantian imperfect duties, however, is controversial among contemporary Kantian commentators. In fact, part of the reason why I reject the interpretation that takes forgiveness as elective is that I do not read imperfect duties in this way. I prefer the rigorist reading which claims that there is no space for acts of supererogation in Kant's moral philosophy. On the rigoristic reading, moreover, the leeway of imperfect duties only allows us to ignore these duties for the sake of other stronger duties. Thus, according to the rigoristic reading there is no open question about whether one should realise the obligatory ends imposed by imperfect duties, but only of how to do it. ${ }^{25}$

Blöser does not attempt to decide the interpretative issue of whether or not Kant's system can accommodate acts of supererogation or whether the latitude of imperfect duties should be interpreted in a relaxed or rigorist way. She merely 'sympathises' with Hill's reading, but it is clear that the claim that Kantian forgiveness is elective requires this reading: we can only maintain that forgiveness is elective in Kant's system if we see wide duties as optional excellences which allow for exceptions due to inclinations. Here I do not have space to provide a full overview of this debate or a full defence of the rigoristic reading. Instead, I will provide a brief summary of what I see as important considerations in support of the rigoristic reading. First, there is ample textual evidence in support of the claim that Kant himself was not very sympathetic to the idea of supererogation. ${ }^{26}$ Second, in addition to the textual evidence, I believe that Timmermann's central argument against making space for the category of supererogation in Kant's system, which appeals to Kant's metaethical views on the nature of moral goodness, is pretty decisive. Famously, the Groundwork opens with the assertion that moral goodness is the only variety of goodness that is unconditionally good (1785/ 1997, G 4:393). Timmermann interprets this as implying that the claims of morality are so weighty that they 'eclipse' any other consideration in support of an action, including prudential considerations. The key point is

\footnotetext{
${ }^{23}$ In a recent paper Per-Erik Milam also notes the tension between simultaneously claiming that forgiveness is elective and that it is something that we do for reasons (2018). Milam, however, does not approach the issue from within a Kantian framework. Here my point is that, from a Kantian perspective, this tension is particularly pressing. As I go on to explain in what follows, given that for Kant, morality is a source of unconditional reasons, if there are moral reasons to forgive, then these cannot be trumped by considerations based on empirical inclinations.

${ }^{24}$ Blöser, 2019, p. 9.

${ }^{25}$ The most important defender of the relaxed reading is Thomas Hill Jr $(1992,2002)$ while Jens Timmermann (2005) has argued forcibly against it. Other important defenders of the rigoristic reading are Marcia Baron (1995, esp. ch. 1) and David Cumminskey (1996, esp. ch.6). As noted recently by Eric Boot (2018) the consensus in the literature seems to be turning towards the rigoristic reading. In addition to citing Timmermann and Baron, Boot also cites Simon Hope (2014) in support of this assertion (fn. 41, p. 67).

${ }^{26}$ Against the possibility of a category of supererogation in Kant's ethical system, Timmermann cites some passages in Kant (1788/ $2002 \mathrm{KpV} 5: 84-85$ and 157) where he seems to dismiss "the idea of grand and noble deeds as high-flown emotional nonsense" (2005, p. 10) and (1790/ $1987 \mathrm{KU} 05: 210)$ in support of the claim that "Kant makes no provision for going 'beyond the call of duty' because duty leaves the agent little room for choice." (p. 10).
} 
that moral goodness always takes precedence over any other kind of value in action to the point that "it silences and eclipses any other claim to value" (Timmermann, 2005, p. 12). ${ }^{27}$ Given that morality is the source of all value, there is no space in Kant for the notion of an action that is morally good yet that can be rationally ignored. From a Kantian perspective, an agent who has a strong moral reason to do something (e.g. forgive), but who nevertheless refuses to do it because she feels so inclined, would be open to the charge of irrationality. If one accepts this view of moral goodness "things [do] not [look] good for supererogation. An action correctly judged to be morally good cannot rationally be rejected in favour of one that is not" (Timmermann 2005, p. 14). ${ }^{28}$ Third, pace Hill, there seems to be consensus among interpreters that, for Kant, imperfect duties of virtue are as equally morally binding as perfect duties of right. ${ }^{29}$ If we allow that imperfect duties can allow for exceptions based on the agent's inclinations or preferences, then it seems difficult to see how these duties can be binding, i.e. whether they are duties at all. ${ }^{30}$ The latitude of imperfect duties results from the fact that such duties command the adoption of maxims and ends, rather than specific actions. On my reconstruction of Kant's position, adopting a maxim of unforgiveness is impermissible. A corollary of this is that adopting a maxim of forgiveness is not merely optional. This relates to the rigoristic reading: there is no question that these obligatory ends ought to be adopted. The latitude relates only to how to realise them. Earlier, I said that I find Blöser's claim that "forgiveness is good in general, i.e. an attitude that we have moral reason to adopt" but that we nevertheless have no direct obligation to forgive in particular cases a bit mysterious. It is not clear what "an attitude that we have moral reason to adopt" but which does not translate into particular duties is supposed to be. What we need is an explanation of what it means to "adopt an attitude of forgiveness in general." My interpretation attempted to provide such an explanation. Inasmuch as forgiveness is a duty of sympathy, it amounts to a duty to shape our character through the adoption of a maxim of forgiveness. It commands us to cultivate a forgiving character through the adoption of a forgiving maxim which requires that we endorse some forgiving attitudes and/ or practices which are deemed appropriate in the circumstances. Thus, the duty to be forgiving is a duty to develop a forgiving character through the adoption of a forgiving maxim, rather than a perfect and direct duty to forgive specific offenders. However, crucially the decision to forgive in specific cases is not merely an issue of inclination, since this could hardly be seen as the expression of a forgiving character shaped by the adoption of a forgiving maxim. Once you have adopted a maxim of forgiving, you have a duty to forgive in specific cases, unless there are other stronger reasons not to forgive in that particular case. The duty is not perfect, so there is always some latitude for the agent to decide when and how ${ }^{31}$ to forgive in specific situations. But Kant says that "a wide duty is not to be taken as permission to make exceptions to the maxim of actions but only as a permission to limit a maxim of duty by another (e.g. love of one's

\footnotetext{
${ }^{27}$ In support of this reading Timmerman cites Kant (1793/ 1996, TP 8:283 and 1788/2002, KpV 5:92-93).

${ }^{28}$ In addition, Timmermann also shows that the moral goodness defined by the categorical imperative does not admit of degrees and that there cannot be a conflict of duties in Kant: when two 'grounds of obligation' conflict, the stronger ground wins out to constitute a duty, all things considered (see 2005, pp. 14-5).

${ }^{29}$ For the view that Kant's duties of virtue are as equally morally binding as duties of right, see Boot (2018, pp. 60-61), Timmermann (2005, p. 21 and 23) and Wood (2009, p. 229).

${ }^{30}$ As correctly stated by Stratton-Lake, interpreting imperfect duties as allowing exceptions in the interest of inclinations robs them of all deontic force. It is not clear how they can be considered duties at all $(2008, \mathrm{p}$. 103).

31 I interpret Kant as committed to a pluralistic notion of forgiveness, so in my account there can be a variety of ways of forgiving wrongdoers.
} 
neighbour in general by love of one's parents)" (1797/ 1991, MS 6:390). ${ }^{32}$ Kant's example refers to the duty of beneficence, but in the case of a duty of sympathy (like the duty to be forgiving), the remark can be read as implying that we might refuse to forgive on occasion, not as a matter of mere inclination or preference, but rather on the basis of stronger moral considerations. Furthermore, I also interpreted Kant's duty to be forgiving as conditional on repentance as evidence of the wrongdoer's commitment to a project of moral self-reflection and self-reform. This amounts to saying that, within the Kantian framework, repentance constitutes a weighty reason to forgive. ${ }^{33} \mathrm{~A}$ person who has adopted a maxim of forgiveness would see repentance as precisely the circumstance that makes forgiveness particularly appropriate. However, such reason can be ignored only if there are other weighty reasons against forgiving, and not simply because one does not feel like it, or is not inclined to do it. My account explicitly allowed for the possibility that, in some cases, the seriousness and heinousness of the wrong might provide a strong consideration against forgiving even those who have repented. ${ }^{34}$ There could be other reasons that make conditional forgiveness inappropriate. A degree of practical judgment and casuistry is required in order to decide on specific cases (1797/1991, MS 6: 411). In short, although we usually have a duty to forgive those who have repented, we might choose not to do so when there are other stronger moral considerations against forgiving. Finally, it also worth emphasising that in my reading of Kant's position, given that I argue Kant's duty to be forgiving is conditional on repentance, and also that some ${ }^{35}$ cases of forgiving the unrepentant are

${ }^{32}$ This is an important passage in favour of the rigoristic reading. The relaxed reading gains support from a passage in the Groundwork which says "I understand here by a perfect duty one that admits of no exception in favour of inclination" (1785/1997, G 4:421n). Hill takes this to suggest that wide duties admit of such exceptions (1992, p. 148; cf. 2002, p. 214 and n. 34). Timmermann notes that this interpretation of the passage is by no means necessary. He takes the passage to imply only that perfect duties admit of no exceptions "in the interest of wider obligation nor in the interest of any other such 'inclination."'...Kant "is lumping together everything that may seem to interfere with strict duty" (p. 16). Thus in this passage, Kant would be emphasising the primacy of perfect duties over imperfect ones: while imperfect duties are restricted by the demands of perfect duties and other imperfect duties, perfect duties admit of no exceptions whatsoever. However, neither type of duty admits of suspensions of duty in favour of an (empirical) inclination (see Timmermann, 2005, esp. pp. 16-8).

${ }^{33}$ I provide a more detailed defence of this interpretation of Kant's theory of forgiveness in Satne (2016, section V). The main idea is that the duties to know ourselves and transform ourselves morally play a key role in Kant's theory of moral development. We have a strong moral reason to forgive repentant wrongdoers because forgiveness can encourage and in fact help the wrongdoer to continue in the path of moral improvement. Commentators disagree as to whether or not Kantian forgiveness should be seen as being conditional on repentance. Sussman (2005a, p. 87) and Moran (2013) also endorse versions of the conditional reading. In contrast, Claudia Blöser (2019), Lucy Allais (2014), Margaret Holmgren (1993), and Owen Ware (2014) have suggested different versions of Kantian-inspired accounts of forgiveness which aim to also reach unconditional cases. The problem with the unconditional reading is that it does not seem to be Kant's own view given that there is direct textual evidence for the conditional reading. In the Lectures on Ethics, Kant explicitly identifies a "duty to prevent offences to oneself" (1793/1997, LE 27: 686) and talks about the need for compensation, apology, or at the very least the acknowledgement of the injustice, presumably stating the need for repentance (1793 /1997, LE 27: 688). Kant explicitly says that if there is no excuse or reparation for an offence, the wrongdoer should show "contrition" and "regret." But if "the injured party is not content with that, then it does a man honour if he offers an apology", noting that "it is not degrading to apologize" (1784-5/1997, LE 27:435). In support of the conditional reading see also 1797/1991, MS 6:461 discussed in section VI of Satne (2016).

${ }^{34}$ See Satne, 2016, p. 1049, fn. 40.

${ }^{35}$ In Satne (2016), I argued that forgiveness of the unrepentant, particularly when we have reasons to believe that their wrongdoing will reoccur, is impermissible because it involves the violation of our duty of self-esteem (see especially section VI). In a more recent paper (Satne, P. Kantian Self-Respect and the Wrongdoing of Others. Unpublished), I provide a more detailed analysis of the forms of forgiveness that are impermissible in a Kantian account. I also qualify my position by allowing for some exceptions, i.e. cases of forgiving the unrepentant which 
impermissible because they conflict with our duties of self-esteem, there is clearly no obligation to forgive the unrepentant, and some cases of doing so might even be impermissible.

Blöser maintains that forgiveness is elective and she seems to leave open the possibility that it can be unconditional. ${ }^{36}$ She needs to emphasise the elective character of forgiveness because otherwise it would be difficult to see how we might rationally ignore the duty to forgive in her account. The problem is that she identifies the reason to forgive as our alleged universal need to be relieved from the burden of moral failure but this seems like a strong reason to forgive. ${ }^{37}$ Furthermore, it seems to be a strong reason to forgive unconditionally, that is, to forgive in all cases. So it is difficult to see how we could refuse to forgive without being deemed irrational unless we read wide duties as allowing for exceptions due to inclination. However, if we reject the relaxed reading of imperfect duties and hence the possibility that forgiveness is merely elective, as I suggested that we should, it is difficult to see why in her account forgiveness is not always obligatory. In contrast, in my reconstruction of the Kantian position, given that for me there is no duty to forgive unconditionally, and some cases of doing so might be impermissible, and given that I allow that even in cases in which the wrongdoer has repented there might be other reasons that make forgiveness inappropriate, there is space to refuse to forgive without being deemed irrational. This is because in my account we might refuse to forgive on rational grounds and not merely as a matter of inclination.

Finally, my motivation to research Kant's theory of forgiveness stems from the fact that I believe that it can offer a distinctive- Kantian- approach to forgiveness. Kant does not use the term elective and, at least in the interpretation that I favour, the notion of electiveness does not sit conformably with the more Kantian notion of imperfect duties. It is better not to assimilate Kant's views into other views in the contemporary literature, however attractive these views might seem. ${ }^{38} \mathrm{I}$ personally find it more interesting to see Kant as offering a third, distinctive, option in the contemporary literature: forgiving is neither a perfect duty, nor is it merely elective. Instead forgiving is an imperfect duty of virtue.

\section{Fallibility}

Blöser claims that "moral fallibility and awareness of moral luck...lead to our having concern for the wrongdoing which is then a reason to forgive" (2019, p. 7, fn. 22). In section 3, I argued that Kant is committed to $1^{*}$ ('there are likely to be circumstances in which we too would fail morally') but that $1^{*}$ does not entail commitment to a weak form of situationism or follows from our awareness of moral luck in any significant substantive sense. Furthermore, although Kant's claim that the "human being has enough guilt of his own to be greatly in need of forgiveness" seems to imply fallibility, it does not explicitly refer to moral luck. As I explained in section 3, I believe that Kant is committed to moral fallibility, not because it follows from a tendency to emphasise the influence of moral luck in the human predicament, but because it follows from his theory of radical evil and moral development. Thus, it seems that awareness of moral luck plays no role in Kant's grounding of the duty to be

do not constitute violations of the duty of self-esteem because the victim has already fought hard to- and in fact succeeded in- overturning oppression.

${ }^{36}$ See e.g. Blöser 2019, p. 16.

${ }^{37}$ I engage with this aspect of Blöser's proposal in section 6.

${ }^{38}$ Lucy Allais is preparing a book on Kantian forgiveness which Blöser quotes (Allais, L. Frailty and Forgiveness: Forgiveness for Humans. Unpublished). Unfortunately, I have not seen the manuscript so I cannot comment on Allais's proposal. 
forgiving. However, for Blöser, moral fallibility plays a key role in the grounding of the Kantian duty to forgive. She claims that "awareness of moral fallibility by itself could be a reason to forgive" (p. 11). This might not be exactly Blöser's position because she goes on to clarify that "moral fallibility grounds a need for forgiveness" and "the fact that forgiveness answers to a need explains why it is an expression of concern" (2019, p. 11). She, then, claims that fallibility gives rise to a need to be relieved of the burden of moral failure and that forgiveness can answer to this need. I discuss this aspect of Blöser's interpretation in the next section. Here I want to discuss the claim that "awareness of moral fallibility by itself could be a reason to forgive" as I find it very problematic. Regardless of whether or not this is exactly Blöser's position, I think it is important to include a discussion of this point here as appeals to moral fallibility are widespread in the contemporary literature on forgiveness. ${ }^{39}$ Now, as we have seen, in the relevant passage Kant refers to our guilt as grounding a need for forgiveness (1797/1991, MS 6: 460). So, it seems that fallibility plays a role in Kant's argument for the duty to be forgiving. However, in what follows I will argue, on systematic grounds, that fallibility per se does not provide a plausible ground for morally appropriate forgiveness. Given how problematic this view is, if there are alternative interpretations available, it would be better to avoid ascribing this view to Kant. I believe that when we consider the different strands of Kant's practical philosophy it is possible to construct an alternative interpretation, one in which fallibility plays a role in the argument for the duty to be forgiving, but where fallibility by itself does not provide the reason to forgive. I provide a brief summary of this reconstruction of Kant's position at the end of this section.

In my view, fallibility by itself presents an unconvincing ground for forgiveness for the following reasons. Firstly, in emphasising that we are all morally fallible, Blöser wants to stress that there are similarities between the victim and the offender. This is a claim that Blöser repeats at various points in her article (e.g. p. 3 and 5). But it seems to me both unkind and unfair to stress the similarities between the perpetrator of wrongdoing and his victim, particularly in cases in which the wrongdoing has been very serious. The claim has some plausibility when we think of relatively minor ordinary, everyday offenses. I can be aware that I am not very good at keeping appointments, so I can forgive you when you fail to return my call. ${ }^{40}$ However, if I have been the victim of a violent sexual assault, the claim that there are similarities between myself and the wrongdoer seems to me to be unwarranted. Although I might be able to recognise that I am morally fallible, after all, falling to keep appointments is a form of disrespecting others, it seems to me that there is a long distance- morally speaking- between failing to keep appointments and violently assaulting another person. The second type of wrongdoing is much more serious as it displays a much deeper disregard for another person's autonomy and dignity. In such cases, to emphasise the 'commonality'11 between the victim and the wrongdoer seems, at best, counter-productive and, at worst, disingenuous. Similarly, in the political realm, there are also different types of conflict. In some conflicts, the opposed groups and actors might all have been guilty of similarly serious forms of wrongdoing. But not all conflicts are like that. Sometimes, there are important moral differences between victims and perpetrators. In many

\footnotetext{
${ }^{39}$ Garrard and McNaughton (2003) are, of course, influential proponents of the need to appeal to human fallibility in discussions about forgiveness.

${ }^{40}$ In a recent paper Cristina Roadevin argues, in my view convincingly, that "someone should not express her blame if she is guilty of the same thing for which she is blaming others, in the absence of an admission of fault" (2018, p. 137). Roadevin argues that this form of blame is morally inappropriate because it involves a form of hypocrisy.

${ }^{41}$ See Garrard and McNaughton 2003, p. 54.
} 
conflicts, there is clearly an actor or group of actors who have been victimised or oppressed by another, more powerful, group or even the state (e.g. the use of rape as a weapon of war in BosniaHerzegovina, ${ }^{42}$ the extermination of Jewish and other minority groups during the Holocaust, or the state terrorism inflicted on Argentine citizens during the dictatorship of 1976-83). It seems to me that it would be highly disingenuous to ask these victims (or victims of similarly horrific conflicts) to be aware of the similarities between themselves and their oppressors. Secondly, and relatedly, while we are all guilty and in need of forgiveness, some are guiltier than others and in need of much more forgiveness. On this account, we have the most reason to forgive the worst offenders, but this is implausible or at least it seems counter-intuitive to me. Thirdly, fallibility does not seem to ground love for ourselves and others but rather accountability. Garrard and McNaughton claim that our "shared humanity" with the offender, which essentially consists in our shared moral fallibility, constitutes a reason to forgive and a reason to be concerned for each other. They call this mutual concern "human solidarity", i.e. the "concern for the wellbeing of those who one feels are in the same condition as oneself" (2003, p. 55). Forgiveness is a way of expressing concern for -or solidarity withthe wrongdoer. They also claim that forgiveness does not only involve overcoming resentment but also having good will and a loving attitude towards the wrongdoer (2003, p. 44, cf. 47). ${ }^{43}$ Now, according to Kant, radical evil is the default position of the human will. Kant talks of this evil as a propensity to prioritise the demands of self-love over moral demands (1793/1998, RGV 30-32). Thus, given this propensity, a self-reflective agent should acknowledge a certain degree of uncertainty about whether or not he would be capable of committing some horrific deeds. After all we cannot know whether we have only been lucky in avoiding the circumstances that would make manifest our evil disposition. This is a really discomforting thought, but inasmuch as we are aware that there is a propensity for radical evil in each of us, Kantian ethics tells that we should attempt to improve ourselves morally, not that we should embrace or even love ${ }^{44}$ this aspect of ourselves. If we don't particularly love or embrace fallibility in ourselves, I don't see why we should love it in others. It is precisely because we are so fallible that we need to hold ourselves and each other accountable. Fallibility ultimately grounds accountability, not love. As noted by Charles Griswold, too much emphasis on human frailty might lead to the view that "it is all the more important- just because we are so frail- to hold ourselves and each other accountable by not forgiving unless there is warrant for doing so" $(2007$, p. 66$) .{ }^{45}$ Fourthly, a weaker point, if fallibility provided a reason to forgive, it would

\footnotetext{
42 This case is discussed in Robin May Schott (2004).

${ }^{43}$ In their 2010 book Forgiveness, Garrard and McNaughton claim that forgiveness requires an "attitude of goodwill towards the perpetrator" which they equate with "wishing him well” (p. 24) but they don't mention love.

${ }^{44}$ Kantian ethics, of course, recommends that we have an attitude of good will towards all persons, including those who have committed terrible deeds: "I cannot deny all respect to even a vicious man as a man; I cannot withdraw at least the respect that belongs to him in his quality as man, even though by his deeds he makes himself unworthy of it" (1797/1991, MS 6:463). However, Kantian good will only requires that we respect others, not that we love them in a pathological sense as this cannot be commanded. The moral law can only command practical love: to strive to perform our duties gladly (1788/2002, KpV 5:83). Respect for persons, however, does rule out hate. Hate is always impermissible as it involves a positive joy at the infliction of suffering on another person, which is contrary to the "end of humanity in [our] own person" (1793/ 1997, LE 27: 686-7). However, respect for persons is not incompatible with appropriate resentment and thus is compatible with a refusal to forgive (for a more detailed discussion of this point, see Satne, 2016, pp. 1046-7).

45 Blöser cites this passage approvingly (p. 6, esp. fn 17). As noted above, Blöser avoids the claim that moral fallibility is a sufficient ground for forgiveness by appealing to the idea that moral fallibility "plays a role in our
} 
only apply to finite rational beings. But presumably we want other rational beings to also have reasons to forgive us. Fifthly, in "Forgiveness and Moral Development", I worried that appealing to our fallibility as a reason to forgive invited us to adopt a morally resigned attitude to each other: "as if wrongdoing is what should be expected from creatures like us." ${ }^{46}$ I claimed that "perhaps the idea is that we should all forgive each other because we are all in need of pardon, so that by forgiving others, we can expect some kind of reciprocity...but if we are all bad, there is no guarantee of reciprocity." 47 To this, Blöser has replied that even though we might not expect reciprocity we might hope for it on the basis of "our recognition of the other as a moral being" (p. 12). Moreover, she points out that hope for reciprocity is not part of Kant's justification of the duty of forgiveness. Rather the justification of the duty appeals to the thought that we should not make exceptions for ourselves: "since I need others to forgive me, I should not on principle refuse to forgive others" (p. 12). I now think that Blöser is right on both points: we might hope for reciprocity (if not expect it) and in any case reciprocity is not an important aspect of the justification of the duty. But I still think that too much emphasis on fallibility invites us to adopt a resigned attitude towards each other, particularly if we allow for unconditional forgiveness (i.e. forgiveness of the unrepentant). This line of thought seems to invite us to see ourselves as so fallible- and likely to continue to act badly- as to continue to require other people's forgiveness and, in turn, be prepared to fulfil a similar need in others. This seems to me like a form of resignation, one that does not do justice to other- more optimistic- aspects of Kant's philosophy. Kant also believes that we are free rational beings capable of transforming ourselves morally. It is precisely because we can be bad that it is important that we commit ourselves to a project of moral improvement. As I explain more fully below, I think a convincing reconstruction of a Kantian theory of forgiveness should take into account this aspect of Kant's philosophy. A final thought on the idea that we should not make exceptions for ourselves: when we think lucidly about it, do we really want (or indeed need) to be forgiven for wrongdoing that we have not acknowledged and not repented? Surely, if we are interested in morality and in our moral development in particular, we want to be forgiven only when we have acknowledged and repented our wrongdoing.

What I am rejecting is the claim that fallibility per se provides a reason to forgive in specific situations by directly grounding our need for forgiveness. However, I still think that fallibility plays a role in the justification of Kant's duty to be forgiving. The justification of the duty to be forgiving takes the acknowledgment of human fallibility as a starting point but it also requires the wrongdoer's commitment to a project of moral self-improvement. My reconstruction of a Kantian argument for the duty to be forgiving appeals to various strands of Kant's practical philosophy, including his theory of rational agency, his theory of radical evil, and his views of moral development. ${ }^{48}$ In order for fallibility to provide a convincing ground for forgiveness, we also need to appeal to the idea that the wrongdoer is committed to the task of becoming a better person. For Kant, to be a moral agent is just to be an agent who is committed to a process of moral self-reflection and self-reform. The fact that the default position of the will is evil means that our fundamental moral task is to transform ourselves morally through a revolution of the heart. When we see that someone has acknowledged their wrongdoing (self-reflection) and is taking steps to repair and repent their wrongs (self-reform), we

duty to forgive because it grounds our need for forgiveness" (2019, p. 6). I discuss Blöser's account of the need to be forgiven in section 6 .

${ }^{46}$ Satne, 2016, p. 1035.

47 Ibidem.

${ }^{48}$ A more careful explanation of this argument is developed in Satne, 2016. 
have a reason to forgive them because our forgiveness can be a way of ratifying their repentance and thus a way of encouraging them to continue on the path of moral improvement. Ultimately, by forgiving them we hope to help them achieve their moral perfection and happiness (Satne, 2016, p. 1046). As Blöser correctly puts it, in my reading, Kant's appeal to our need to be forgiven stems from the fact that forgiveness can be a form of affirmation and encouragement which can help us in our quest for moral improvement. ${ }^{49}$ Furthermore, encouragement and affirmation are important not only for the moral development of each person but also because they can help us in our quest to collectively overturn radical evil by helping us to restore relationships and reintegrate offenders into the community. ${ }^{50}$ However, this argument only yields conditional forgiveness, that is, forgiveness of the repentant.

Blöser says that my explanation of the need for forgiveness "holds promise for repentant wrongdoers" but she "wants not to exclude the possibility that even non-repentant wrongdoers might have a need for forgiveness" and argues that "we should search for an account that covers those cases as well" (p. 16). ${ }^{51}$ Blöser finds support for her interpretation in Kant's claim that the "human being has enough guilt of his own to be greatly in need of forgiveness" (1797/ 1991, MS 6: 460). However, the passage is a bit cryptic and, as Blöser herself notes, it does not amount to an account of the need to be forgiven (p. 2 and p. 15). Thus she complements Kant's account with her own account of this need. Her proposal is to interpret the need to be forgiven as a need to be relieved from the burden of our moral guilt. In the next section, I discuss Blöser's proposal. I will rely on arguments developed in previous and forthcoming work, so my discussion will be brief in order to avoid overlapping with these works. I will claim that Blöser's proposal is in contrast with some central aspects of Kant's conception of moral guilt. I will argue that our moral guilt cannot be completely overcome and that, to the extent that it is possible and desirable to ameliorate our felt guilt, this requires the wrongdoer's repentance. A recognisable Kantian account of the need to be forgiven should indeed be restricted to repentant wrongdoers.

\section{The need for forgiveness}

Blöser's analysis starts by providing an explanation of why, from a Kantian perspective, moral failure is experienced as a burden. This is because we care about moral demands even when we fail to live up to them. Kant claims that the moral law is the most basic 'fact of reason,' available to every rational being, claiming that consciousness of moral obligation is compatible with each type of human evil (1973/1998, RGV 6: 35). The discrepancy between our awareness of moral obligation and our moral failure constitutes a burden for us. The pangs of conscience represent one aspect of this burden. In

\footnotetext{
49 Blöser offers a good reconstruction of my position in pp. 14-15.

${ }^{50}$ See Satne, 2016, p. 1050.

${ }^{51}$ In fn. 51 (p. 16) Blöser says that claiming that unrepentant wrongdoers might have a need for forgiveness does not imply the different thesis that forgiving the unrepentant is permissible. However, I think that in Blöser's account it is difficult not to conclude that if the unrepentant have a need for forgiveness, then we have a reason to forgive them, and forgiving the unrepentant is permissible. This conclusion seems unavoidable because, according to her, it is our awareness of our moral fallibility that grounds our need for forgiveness, which, in turn, grounds a wide duty to forgive. Moreover, Blöser claims that 'the topic deserves a discussion of its own', but her account does not provide any indication of why she might think that forgiveness of the unrepentant is problematic for Kant. Also, a Kantian theory of forgiveness surely should include a discussion of this important point.
} 
addition, the wrongdoer also experiences "painful awareness that another person harbors resentment towards her" so that we might say that "the other's resentment is the social aspect of the burden of moral failure" (p. 17). Moreover, Blöser endorses Allais's proposal that as "moral agents who fail we are in danger of succumbing to either despair or self-deception" (Ibidem). We despair when we collapse under this burden while we might self-deceive in order to avoid altogether the feeling of being burdened. According to Blöser, we need to be relieved of the burden of moral failure in order to ward off despair and self-deception because these are "obstacles not only to happiness but also to moral behaviour" (Ibidem). Blöser then argues that forgiveness can provide a relief from the burden of our moral guilt, thus providing an account of our alleged need for forgiveness. Forgiveness relieves us from the social aspect of the burden because the victim has now overcome her resentment, so at least this aspect is no longer present. Moreover, Blöser writes: "Presumably, forgiveness relieves us of the burden in an even more general way (...) Forgiveness means that the wrong "does not count" anymore, at least not in terms of the other's affective attitudes (...), and this may motivate the wrongdoer to adopt a similar attitude and stop perceiving the wrong as a psychological burden" (Ibidem).

In 'Forgiveness and Punishment in Kant's Moral System' (2018), I noted that Kant's claim that 'we are all in need of forgiveness because we have enough guilt of our own' seems to be in tension with a passage in the Religion in which Kant states that the debt for our evil disposition, and presumably the immoral particular actions ensuing from it, "is a debt which is impossible for [man] to wipe out" (1973/1998, RGV 6:72). In this very same passage Kant says that this debt cannot be erased by someone else because it is not a transmissible liability similar to a financial debt but "the most personal of all liabilities, namely a debt of sins which only the culprit, not the innocent, can bear..." (Ibidem). I took this passage as evidence that, for Kant, other's forgiveness cannot help to erase the wrongdoer's moral guilt. I also argued that the passage should not be read as appealing to divine forgiveness because then it would be in conflict with some fundamental commitments of Kant's practical philosophy. ${ }^{52}$ I concluded that "Kant's conception of forgiveness does not, and cannot, require the overcoming of moral guilt" (2018, p. 214). ${ }^{53}$

In a more recent paper entitled "Kantian Guilt" 54 I specifically discuss Blöser's account of the need to be forgiven. I draw on Kant's discussion of moral guilt in the second Critique (1788/2002, KpV 5: 9899) in order to show that, for Kant, guilt involves both an intellectual and an affective aspect. In the intellectual sense, guilt consists in passing a guilty verdict (judgment) regarding our violations of the moral law: "the lawyer that speaks in his favour can in no way silence the prosecutor in him" (1788/2002, KpV 5: 98). In addition, Kant also identifies repentance as a painful affect which accompanies this judgement of guilt: "repentance is a painful sensation which is brought about by a moral attitude" (Ibidem). There are two main features of Kant's discussion that are relevant here. The first is Kant's interesting observation that it is indeed guilt that proves the reality of freedom (1788/2002, KpV 99-100). ${ }^{55}$ When we reflect lucidly about our past wrongdoing, if our actions were

\footnotetext{
${ }^{52}$ Pasternack (2012) provides a good discussion of the difficulties associated with interpreting Kant as appealing to divine forgiveness in order to help us overcome our moral guilt.

${ }^{53}$ For further details of this argument, see Satne, 2018, pp. 213-215.

${ }^{54}$ This paper was presented at the $13^{\text {th }}$ International Kant Congress held in Oslo in August of 2019. I expect the paper will be published in the Proceedings of the Congress.

${ }^{55}$ The link between guilt and our awareness of our freedom that Kant makes in these passages is also emphasised by Zupančič (2000), pp. 21-42 and Gamberini (2013).
} 
objectively wrong, and we are conscious of the commands of the moral law, then we cannot but judge ourselves as guilty. However, this means that we ultimately take responsibility for our actions and that we take ourselves as free in the sense that we now think that we could have acted otherwise in those same circumstances. An acknowledgment of our fundamental freedom is implicit in judging ourselves as guilty. The second relevant feature is that it seems to follow from this discussion that we cannot overcome our intellectual moral guilt. This is because any sincere realisation of a past, objectively wrongful act would involve a verdict of guilty. Furthermore, this judgement will be accompanied by affective guilt, that is, repentance in the sense of painful remorse. Consequently, intellectual guilt cannot be fully overcome, and, as I briefly argue below, affective guilt can at most be ameliorated, but only through a process of moral self-transformation, and not by other people's forgiveness. ${ }^{56}$

Blöser thinks that forgiveness might help the wrongdoer to overcome the social aspect of the burden of moral guilt, which in turn could help the wrongdoer to ward off despair and/ or self-deception. However, I will argue that, from a Kantian perspective, ameliorating moral guilt- to the extent that it is possible- always requires moral self-transformation. Moreover, the victim's unconditional forgiveness, in the absence of the wrongdoer's repentance, would ultimately fail to help the wrongdoer to ward off despair and/ or self-deception. For this repentance is also necessary. First, an evil person in the Kantian sense can avoid acknowledging their own guilt, and therefore the painful side of repentance, but only through a process of self-deception. For Kant, wrongdoing involves mistakenly taking merely subjectively valid motives to have objective justification. As noted by Andrews Reath, "the different tendencies that this description fits might share the feature of being sustained by some set of false or impoverished beliefs. These could range from beliefs about one's motives or the relevant features of one's situation, to beliefs about practical reason or the moral capacities of the self (...). [Thus] the influence of self-love on the will is sustained by an ideology of sorts, which enables individuals to view their maxims as objectively acceptable reasons." ${ }^{57}$ I do not have space here to include a full discussion of Kant's theory of evil but I see Reath's proposal as a plausible reading of Kant. Within the Kantian framework, then, evil- in the sense of immorality- often amounts to, or is sustained by, a form of self-deception. Blöser speculates that forgiveness can help someone to avoid self-deception because it can help them to overcome the social aspect of the burden of moral guilt. However, it is not clear that forgiveness necessarily has this effect on the unrepentant who by definition are not burdened by their guilt. The immoral person is likely to succumb to selfdeception but not because she fails to overcome her moral guilt. On the contrary, the immoral person succumbs to self-deception precisely because she fails to acknowledge her own guilt. Avoiding selfdeception requires self-scrutiny and self-criticism. Ultimately, avoiding self-deception requires that we be prepared to recognise, acknowledge, and accept our past wrongdoing. This task is particularly difficult given Kant's insistence on the opacity of our own maxims ${ }^{58}$ but it is something that we nevertheless have a duty to strive for. ${ }^{59}$ Moreover, in the case of unrepentant wrongdoers, refusing to forgive (rather than forgiving them) might prove a more effective way of encouraging them to acknowledge their wrongdoing. This can give rise to repentance understood as a firm commitment to

\footnotetext{
${ }^{56}$ For a more detailed explanation as well as arguments in support of this claim, see section 3 in P. Satne "Kantian Guilt." Unpublished.

${ }^{57}$ Reath, 2006, p. 21. Reath provides an interesting analysis of the different tendencies that might be involved in erroneously taking mere subjective grounds of action as having objective or justifying force.

${ }^{58}$ This is a well-known Kantian claim. See e.g. 1793/1998, RGV 6:20.

${ }^{59}$ In fact, Kant says that self-scrutiny is the first command of all duties to oneself (1797/1991, MS 6:441).
} 
change one's maxims and engage in a project of moral transformation. ${ }^{60}$ Thus, refusing to forgive in some cases might be more conducive to encouraging someone to avoid self-deception than actually forgiving them (at least initially in the absence of repentance, remorse, and/ or apology).

Second, for the moral person, the person who is struggling to make the moral law the supreme principle of all her actions, the acknowledgement of guilt will be accompanied by repentance both in the sense of painful remorse but also, more intellectually, in the sense of coming to reject her immoral actions and committing to abandon their underlying maxims. ${ }^{61}$ In this type of case, the acknowledgement of guilt is likely to be accompanied by a commitment to a project of moral transformation which involves self-reflection and self-reform. Crucially, recognising and acknowledging our guilt does not have to lead us to despair in the sense of collapsing under the burden of our moral guilt. As noted above, Kant argues that it is precisely our moral guilt that helps us to recognise our fundamental freedom. On Kant's account, therefore, acknowledging and repenting our guilt can represent an opportunity for change and moral improvement and it can provide the basis for taking an optimistic view of the self which, according to Blöser and Allais, is a necessary condition for the very possibility of moral agency (Blöser, 2018, p. 16). Moreover, when we become hopeful about our prospects of becoming better people, it is likely that the felt aspect of guilt (remorse) will be ameliorated so the psychological pain will not be so burdensome.

In my view, what this analysis shows is that the process of ameliorating the burden of our guilt, to the extent that this is at all possible within the Kantian framework, involves a process of selftransformation rather than depending on other people's attitudes, including their forgiveness. I do not deny that other people's forgiveness might play a role here. After all, according to my account, forgiveness is necessary because it can be a way of ratifying the wrongdoer's repentance and a way of encouraging them to continue on the path of moral improvement. What I deny is that the victim's forgiveness can motivate the wrongdoer to stop perceiving the wrong as a psychological burden in the absence of the wrongdoer's repentance as part of a commitment to a project of moral selftransformation. From a Kantian perspective, a wrongdoer can stop perceiving their past wrongdoing as a burden only when they are committed to maximizing their efforts to improve morally. Repentance involves the recognition of our own guilt, a guilt that cannot be fully erased. But, recognition of this guilt is also an opportunity for acknowledging our fundamental freedom and therefore a chance for moral improvement. Ultimately, repentance is necessary to ward off despair and self-deception. In the Kantian account, then, it is incoherent to assert simultaneously that forgiveness can both help us to overcome the social aspect of our moral guilt and be given unconditionally.

\section{Conclusion}

\footnotetext{
${ }^{60}$ This point is well-explained by Miranda Fricker's account of Communicative Blame: "the perlocutionary point of Communicative Blame is to prompt a change for the better in the behaviour (inner and outer) of the wrongdoer" (2016, p. 173).

${ }^{61}$ The intellectual interpretation of repentance as the commitment to abandon immoral maxims and become a better person is defended in Satne, 2016, p. 1044. Further support for this reading is found in the Lectures on Ethics where Kant explicitly rejects the notion of repentance as a form of self-punishment or chastisement (17845/1997, LE 27:464). However, Kant still maintains that "inner contrition for our offences and the firm resolve to live a better life" is the most helpful thing to us and others (ibidem) thus suggesting a more intellectual notion of repentance.
} 
Blöser's interpretation of a recognisable Kantian account of forgiveness is deep and illuminating. I am grateful to Blöser for discussing some aspects of my proposal. My understanding of Kant's position has certainly been enriched by engaging in this debate. There are a lot of points of agreement between our interpretations of Kantian forgiveness. But the aim of this article has been to point out that there are also important points of disagreement. I have argued that, for Kant, the duty to be forgiving is an imperfect duty of virtue and that it is best not to interpret imperfect duties as being elective in the sense specified by Blöser. I have also argued that, for Kant, our moral record is a function of our character, not our circumstances, and consequently Kant is not committed to situationism, not even of a weak kind. I also argued that moral fallibility by itself does not provide a convincing ground for morally appropriate forgiveness. Finally, I showed that, within the Kantian framework, the need to be forgiven cannot amount to a need to be relieved from the burden of our moral guilt. Ultimately, within the Kantian account it is incoherent to assert simultaneously that forgiveness can both motivate us to overcome our moral guilt and be given unconditionally. Forgiveness, for Kant, is necessary as affirmation of repentance and encouragement to continue on the path of moral improvement.

\section{$\underline{\text { References }}$}

\section{Kant's works}

Abbreviations and translations used are as follows:

Kant, I. (1784-5) LE: Vorlesungen Wintersemester Moralphilosophie Collins. English edition: Kant, I. (1997). Moral philosophy: Collins's lecture notes. In Lectures on Ethics (trans: Peter Heath and edited by Peter Heath and J.B. Schneewind). Cambridge: Cambridge University Press.

Kant, I. (1785). G: Grundlegung zur Metaphysik der Sitten. English edition: Kant, I. (1997). Groundwork of the Metaphysics of Morals (trans: M. Gregor and introduction by C.M Korsgaard). Cambridge: Cambridge University Press.

Kant, I. (1788). KpV: Kritik der praktischen Vernunft. English edition: Kant, I (2002). Critique of Practical Reason (trans: W.S. Pluhar and introduction by S. Engstrom). Indianapolis: Hackett Publishing Company, Inc.

Kant, I. (1790). KU: Kritik der Urteilskraft. English edition: Kant, I. (1987). Critique of Judgment (trans and introduction by W.S. Pluhar). Indianapolis: Hackett Publishing Company, Inc.

Kant, I. (1793) LE: Vorlesungen Wintersemester Metaphysik der Sitten Vigilantius. English edition: Kant, I (1997). Kant on the metaphysics of morals: Vigilantius's lecture notes. In Lectures on Ethics (trans: Peter Heath and edited by Peter Heath and J.B. Schneewind). Cambridge: Cambridge University Press.

Kant, I. (1793) TP: Über den Gemeinspruch: Das mag in der Theorie richtig sein, taugt aber nicht für die Praxis. English edition: Kant, I. (1996). On the common saying: that may be correct in theory, but It Is of no use in practice. In The Cambridge Edition of the Works of Immanuel Kant (trans: Mary J. Gregor and introduction by Allen Wood). Cambridge: Cambridge University Press. 
Kant, I. (1793). RGV: Die Religion innerhalb der Grenzen der bloßen Vernunft. English edition: Kant, I. (1998). Religion within the Boundaries of Mere Reason and Other Writings. (trans: A.W. Wood and G. di Giovanni and introduction by R. M. Adams) Cambridge: Cambridge University Press.

Kant, I. (1797). MS: Die Metaphysik der Sitten. English edition: Kant, I (1991). The Metaphysics of Morals (trans: M.J. Gregor). Cambridge: Cambridge University Press.

\section{Other works}

Allais, L. (2013). Elective forgiveness. The International Journal of Philosophical Studies, 21(5), 637653.

Allais, L. (2014). Freedom and forgiveness. In D. Shoemaker \& N. Tognazzini (Eds.), Oxford Studies in Agency and Responsibility, volume 2: 'Freedom and Resentment.' Oxford: Oxford University Press, 33-61.

Allais, L. (2015). What properly belongs to me: Kant on giving to beggars. Journal of Moral Philosophy $12,754-71$.

Baron, M. (1995). Kantian Ethics Almost without Apology. Ithaca: Cornell University Press.

Blöser, C. (2019). Human fallibility and the need for forgiveness. Philosophia, 47, 1-19.

Boot, E. (2018). Judging rights by their duties: a Kantian perspective on human rights. In Krasnoff, L., Sanchez Madrid, N. and Satne, P. (eds) Kant's Doctrine of Right in the $21^{\text {st }}$ Century. Cardiff: University of Wales Press.

Cumminskey, D.(1996). Kantian Consequentialism. Oxford and New York: Oxford University Press.

Drogalis, C. "Kant's Change of Heart: Radical Evil and Moral Transformation" (2013). Dissertations. 512. https://ecommons.luc.edu/luc_diss/512

Fricker, M. (2014) What's the point of blame? A paradigm based explanation. Nous, 50 (1), 165-183.

Gamberini, P. (2013). Guilt and Repentance: Kant on the Experience of Moral Responsibility in the Retrospective Evaluation of Actions. Kant und die Philosophie in weltbürgerlicher Absicht: Akten des XI. Kant-Kongresses 2010 (pp. 233-244).

Garcia , E. V. (2011). Bishop Butler on forgiveness and resentment. Philosophers' Imprint, 9 (10), 119.

Garrard, E., \& McNaughton, D. (2003). In defense of unconditional forgiveness. Proceedings of the Aristotelian Society, 103(1), 39-60.

Garrard, E., \& McNaughton, D. (2010). Forgiveness. Acumen Publishing Limited.

Griswold, C. L. (2007). Forgiveness. A philosophical exploration. New York: Cambridge University Press.

Hallich, O. (2016). A plea against apologies. Philosophia, 44 (3), 1007-1020. 
Hill, T. (1992). Kant on imperfect duty and supererogation. In Dignity and Practical Reason in Kant's Moral Theory. Ithaca, London: Cornell University Press, 147-175.

Hill, T. (2002). Meetings needs and doing favors. In Human Welfare and Moral Worth. Oxford: Oxford University Press.

Holmgren, M. (1993). Forgiveness and the intrinsic value of persons. American Philosophical Quarterly,30(4), 341-52.

Hope, S. (2014). Kantian imperfect duties and modern debates over human rights. The Journal of Political Philosophy, 22(4), 396-415.

Korsgaard, C. M. (1996). Creating the kingdom of ends. Cambridge: Cambridge University Press. Milam, P. E. (2018). Against elective forgiveness. Ethical Theory and Moral Practice, 21(3), 569-584. Moran, K. A. (2013). For Community's Sake: A (Self-Respecting) Kantian Account of Forgiveness. Proc. Of XI International Kant Congress, 433-444.

Pasternack, L. (2012). Kant and the debt of sin. Faith and Philosophy, 29(1), 30-52.

Reath, A. (2006). Kant's theory of moral sensibility: respect for the moral law and the influence of inclination. In Agency \& Autonomy in Kant's Moral Theory. Oxford: Clarendon Press.

Roadevin, C. (2018). Hypocritical blame, fairness, and standing. Metaphilosophy, 49 (1-2), 137-152.

Satne, P. (2013). Reliability of motivation and the moral value of actions. Studia Kantiana, 14, 5-33.

Satne, P. (2016). Forgiveness and moral development. Philosophia, 44 (3), 1029-1055.

Satne, P. (2018). Forgiveness and punishment in Kant's moral system. In Krasnoff, L., Sanchez Madrid, N. and Satne, P. (eds) Kant's Doctrine of Right in the $21^{\text {st }}$ Century. Cardiff: University of Wales Press.

Scarre, G. (2004). After evil. Responding to wrongdoing. Aldershot: Ashgate Publishing Limited.

Schott, R.M (2004). The atrocity paradigm and the concept of forgiveness. Hypatia, 19(4), 2014-211.

Stratton-Lake, P. (2008) Being virtuous and the virtues: two aspects of Kant's doctrine of virtue. In Betzler, M.(ed.), Kant's ethics of virtue. Walter de Gruyter \& Co, 101-122.

Sussman, D. (2005a). Kantian forgiveness. Kant-Studien, 96(1), 85-107.

Sussman, D. (2005b). Perversity of the heart. The Philosophical Review, 114(2), 153-77.

Timmermann, J. (2005). Good but not required? Assessing the demands of Kantian ethics. Journal of Moral Philosophy, 2(1), 9-27.

Ware, O. (2014). Forgiveness and respect for persons. American Philosophical Quarterly, 51(3), 247260.

Williams, G. (2018). The social creation of morality and complicity in collective harms: a Kantian account. Journal of Applied Philosophy. https://doi.org/10.1111/japp.12334 
Wood, A.W. (2009). Duties to oneself, duties of respect to others. In T. E. Hill Jr. (Ed.), The Blackwell guide to Kant's ethics. Oxford: Blackwell Publishing Ltd.

Zupančič, A. (2000). Ethics of the real. Kant, Lacan. London and New York: Verso. 